\title{
Jugular Bulb Prolapse: One New Case
}

\author{
Z.Chafiki*, S Anajjar, M Khdim, S Rouadi, R L Abada, M Roubal, and M Mahtar \\ Department of ENT, Ibn Rochd University Hospital Casablanca, Morocco
}

Submission: February 20, 2017; Published: July 20, 2017

*Corresponding author: Chafiki zakaria, Department of ENT, 20 Aout Hospital, Ibn Rochd University, Hospital Casablanca, Morocco,

Email: zakaria.chafiki@gmail.com

\section{Abstract}

The constatation of a right retrotympanic blue mass imposes a precise exploration before any surgery. By reporting an observation of a jugular bulbprolapse, Hence the interest of tomographyin the positive diagnosis of these anomalies to avoid despaises and serious complications during otological surgery.

Keywords: Bulb; Jugularvein; Eardrum; Tomography

\section{Introduction}

The anatomical variations of the hypotympanum essentially combine the more or less marked prolapse and dehiscences of the bulb of the jugular and the internal carotidartery. These abnormalities should not be over looked as they may alter the normal course of the surgical sequence. A recent observation illustrates that a well-conducted clinical examination may not always suggest a prolapse bulb of the jugular in the middle earcavity. This raises the question of the value of systematic imaging before any surgery of the middle ear with pathological ear drum.

\section{Case Report}

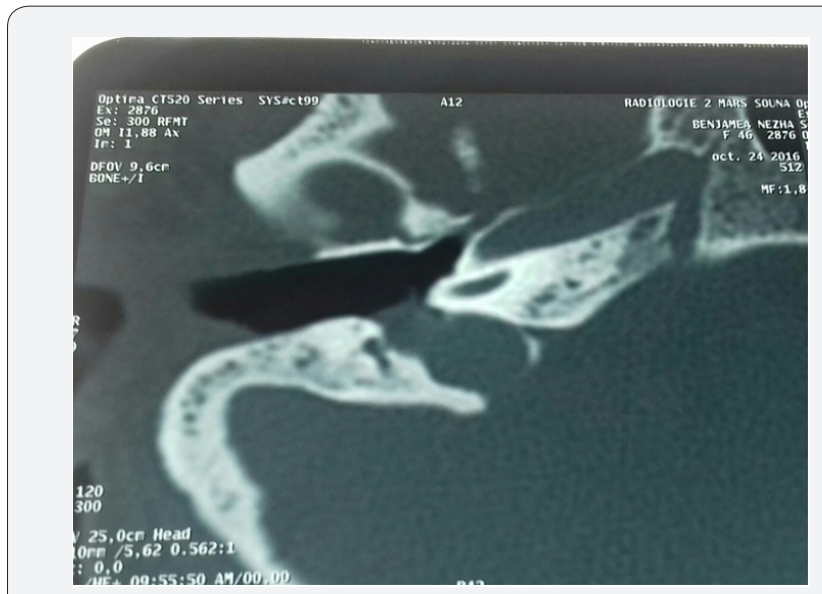

Figure 1: Axial computer-tomographic scan section showing the dehiscence of the bulb of the jugular.
A 45-year-old woman with a chronicotorrhea, hypoacousia of the right ear for 2 years without vertigo or facial paralysis. The clinical examination shows an uncontrollable anterior retraction pocket with a bluish appearance postero inferior. The contralateralear was normal.

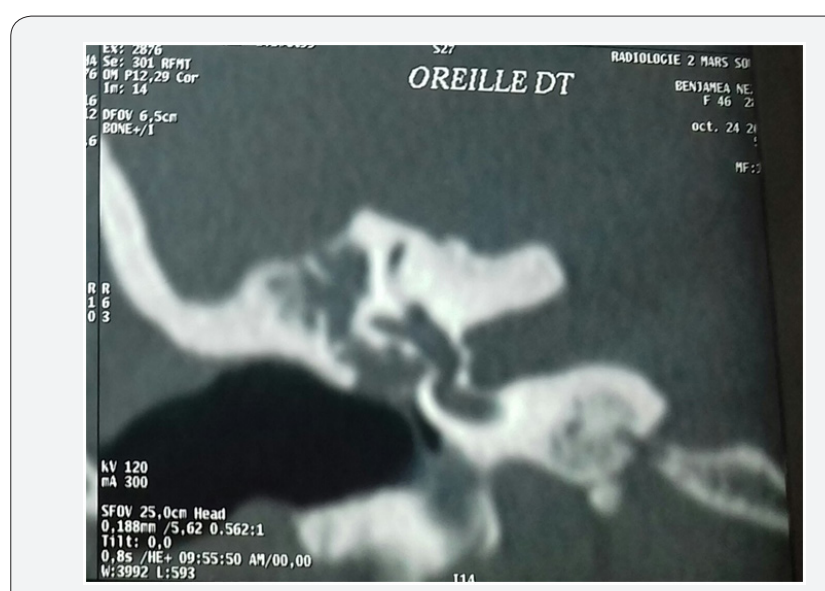

Figure 2 : coronal computer-tomographic scan section showing the dehiscence of the bulb of the jugular.

Computed Tomography of the patient's temporal bones was requested. This imagery allows us to discover an anatomical anomaly, in the form of an important anectatic right Jugular Bulb, located at the postero-inferior part of the middle-ear cavity (Figure $1 \& 2$ ). In addition to that a lateral sinus prolapse was observed (Figure 3). 


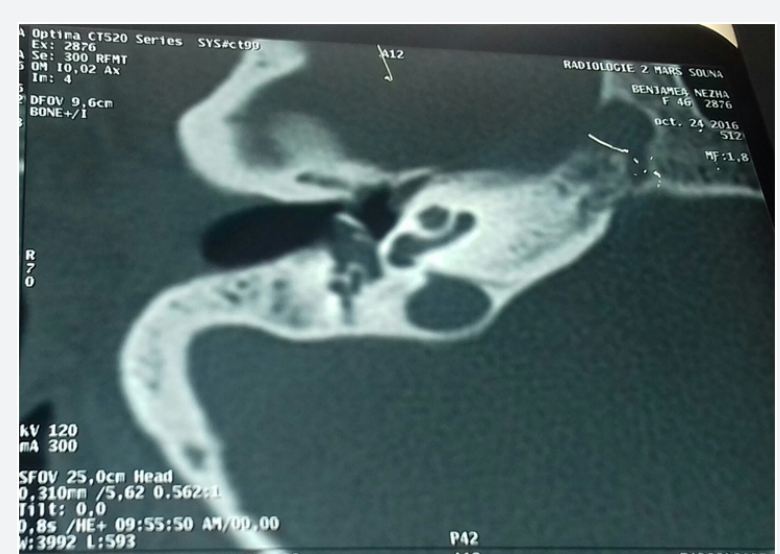

Figure 3 : Axial computer-tomographic scan section showing the dehiscence of the sigmoid sinus.

A technique: tympanoplasty in closed technique was proposed. The topography of this anatomical variant of the jugular vein encourages us to be more cautious during the procedure. A careful dissection allows a complete detachment of the flap, and a good progress of the continuation of the intervention, weper formed a resection of the malléusand the incus with reinforcement pocket of retraction by cartilage of the conch.

\section{Discussion}

The anatomical variations of the middle ear are well known. The ones about the jugular bulb remains uncommon [1], Whereas the dehiscences of the carotidduct, although they are more often described in the classical works [2-3], are even more rarer (1.4\%) [4]. Indeed, dehiscence of the bulb is diagnosed in $2.4 \%$ [5] to $3.9 \%$ [4] of cases, whereas the presence of a Highriding jugular bulb covered with a bonelamellais more frequent, Up to $20 \%$ of cases for Atilla et al. [4]. Development appears to be increasingly important on the right [6-7], which is indeed the case in the present case.

If the variations in height and topography are numerous, more emphasis will be placed on the clinical presentation of such an anomaly. A clinical examination, with a normal or subnormal eardrum, mayevoke an ectopia of the bulb if we notice an coving or a bluish mass by transparency. In the case of chronicotitis media, with an inflammatory tympanum or the presence of a polypus, examination is much more difficult.

The systematic demand for computed to mography allows us to make a lesional assessment of the cholestéatome, as well as its extension. It also shows the classic anatomical landmarks and, finally, looks for possible anatomical abnormalities. The interest of such research is to guide us, not so much in the indication as in the topographical approach of the the middle ear cavity. Indeed, a classic approach to the lower part of the frame would have immediately led to a profuse bleeding of venous blood with postponed surgery. The principle of haemostasis is limited to local compression with the head decolding in order to prevent gasembolism [8].

The more posterior approach allowed us to correctly expose the abnormal region. Therefore, dissect with more security.

\section{Conclusion}

The anatomical variations of the bulb of the jugular are not so rare. Those that may be problematic are related to significant prolapse and / or associated dehiscence, making the venous wall vulnerable.

There is a real surgical haemorrhagic risk. Is it necessary to do imaging before any ear surgery? Certainly not. In the particular case of cholestéatome, the systematic use of a computed tomography (CT) was reported at the Sixth Frenchspeaking Congress of ENT and CCF in Beirut. The problem is to target situations where this exploration is justified. The current medico-legalevolution, which requires us to inform the patient of the risks of surgery, is an additional reason for requesting a preoperative scan of the rock in the presence of an abnormaleardrum in its postero-inferior part.

\section{References}

1. Thomassin JM, Belus JF (1995) Anatomy of the middle ear. Encycl Méd Chir Ear, Nose and Throat 20-015-A-10, 5.

2. Paturet G Traité d'anatomie humaine. Masson, Paris T1, p. 156.

3. (1986) Surgical anatomy of the ear and temporal bone. In: Proctor B (Ed.), Thieme Med Pub, New York, 11

4. Atilla S, Akpek S, Uslu S, Ilgit ET, Icsik S (1995) Computed tomographic evaluation of surgically significant vascular variations related with the temporal bone. Eur J Radiol 20(1): 52-56.

5. Tomura N, Sashi R, Kobayashi M, Hirano H, Hashimoto M, et al. (1995) Normal variation of the temporal bone on high-resolution CT: their incidence and clinical significance. Clin Radiol 50(3): 144-148.

6. Guitrancourt AJ, Marie JP, De Sevin E, Dehesdin D (1995) Ectopie du golfe de la jugulaire et du sinus latéral dans le conduit auditif externe. J Fr Otorhinolaryngol 44(3): 200-203.

7. Aslan A, Falcioni M, Russo A, De Donato G, Baylan FR, Taibah A, et al. (1997) Anatomical consideration of high jugular bulb in lateral skull base surgery. J Laryngol Otol 111(4): 333-336.

8. Moore PJ (1994) The high jugular bulb in ear surgery : three case reports and a review of the literature. J Laryngol Otol 108(9): 772-775. 


Your next submission with Juniper Publishers
will reach you the below assets
- Quality Editorial service
- Swift Peer Review
- Reprints availability
- E-prints Service
- Manuscript Podcast for convenient understanding
- Global attainment for your research
- Manuscript accessibility in different formats
( Pdf, E-pub, Full Text, Audio)
- Unceasing customer service
Track the below URL for one-step submission
https://juniperpublishers.com/online-submission.php

